\title{
Employee's Resistance and Organizational Change Factors
}

\author{
Gentisa Furxhi
}

\section{ABSTRACT}

Organizations need to change due to challenges they are facing caused by the dynamic environment where they operate. Also, organizations undertake changes because they have new ideas to improve their performance. So, organizational changes are imposed by factors of external or internal environment. The aim of every change is to improve organizational performance by increasing its effectiveness. Sometimes, changes are proposed during crises time. In crisis's situation, organizations need to cut their costs, and the most common change is reducing staff.

In every situation, change is something new for employees. Change affect employees because they are going to implement it. They can show positive attitude/behavior (readiness to change) or negative attitude/behavior (resistance to change) to proposed change. When employees show positive attitude, they agree on change and they are motivated to implement it. On the other hand, negative attitudes reflect that employees do not agree to organizational change. They are not motivated to involve in organizational change and sometimes they refuse it. Change managers are interested to have employees which are motivated and opened to change because this can lead to a successful change management process. On the other side, resistance to change can lead to the failure of change, because resistance may create costs and delays into change management process.

This paper will explain which factors impose organizations to undertake changes time to time. Also, it will analyze how employees behave during organizational change. The aim of this paper is to explain why employees resist to organizational change and how can change managers reduce employee's resistance.

Keywords: employees, organizational change, readiness to change, resistance to change.
Submitted : February 19 **, 2021

Published : March 12, 2021

ISSN: $2507-1076$

DOI: $10.24018 /$ ejbmr.2021.6.2.759

\section{Gentisa Furxhi*}

University "Fan S. Noli", Economic

Faculty, Korca, Albania.

(e-mail: gfurxhi@gmail.com)

*Corresponding Author

\section{INTRODUCTION}

Nowadays, organizational environment is characterized by complexity and competitiveness. Organizations due to this environment, have to undertake changes to remain profitable and competitive. Organizational changes may affect organizational culture, good and services, technology, organizational structure, or strategy. Sometimes, change creates a situation which generates a high level of discomfort for the employees [4].

Employees attitude or behavior regarding change depends by their individual perceptions. Also, they are influenced by organizational past experiences of change management or how much available information do they have regarding change. Employees can show positive attitude/behavior (readiness to change) or negative attitude/behavior (resistance to change) to proposed change.

Employees role in change management is crucial because they are the key factor of change implementation. Therefore, many researchers had studied the role of employees in change management [1], [5], [6].

Some authors stressed that $70 \%$ of all change initiatives fail, because managers did not understand the process of change management [2]. Employees resistance to change have been seen as a potential factor to change failure. Resistance is connected to negative attitudes or behaviors. Resistance to change is an essential factor to be considered in any change process since resistance is a key for failure [8], [12]. However, some researchers had claim that resistance to change is not a completely negative element, because when it is based on real arguments against change it contribute to improve change management process [13].

\section{ORganizational Change FACtors}

Organizations do not operate in vacuum; they are open systems that exchange with their external environment. Also, organizations have their own internal environment. Organizations need to change due to factors of internal and external environment. External factors that force organization to change are:

a) economic factors;

b) technological changes;

c) social changes;

d) costumers needs for goods and services.

Economic factors- Macroeconomic factors such as the rate of inflation and unemployment, monetary and fiscal policies of the government, are causes that have a high influence on 
organizations. Managers need to track these indicators in order to make the right decisions for change.

Technological changes- Organizations have to adopt technological change that is shown in its industry environment. Technological changes may force organizations to undertake big or small change. When the organizations adopt new technology, its work structure is affected, and a new equilibrium has to establish.

Social changes- Society has changed. Most social changes are level of educations, urbanization, feeling of autonomy, etc. These changes affect employee's behavior in the workplace. Organizations have to understand employees' desires in order to match their desires with their work, or to change the way they motivate their employees.

Costumers desires for goods and services- Costumers needs and desires change time to time. These changes force the organizations to bring those products which meet the buyer's requirements.

Internal factors that force organizational change are:

a) employees;

b) organization structure;

c) organizational processes.

Employees- They bring changes in organizations. They change methods of working for being more productive or effectiveness in their work.

Organizational structure- is an internal source for organizational change. Structure defines the authority and the hierarchy in a company. Sometimes, organizations have to reorganize their structure because the old structure does not afford new challenges.

Organizational processes- are activities that produce an output. These activities need to change in order to accomplish organizational objectives or costumers' desires which change over time.

External and internal factors of organizational change are shown in figure below (Fig. 1).

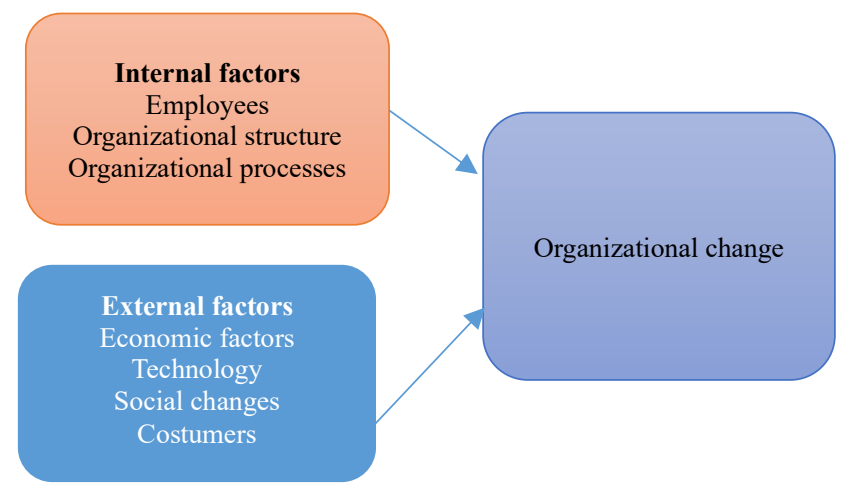

Fig. 1. Organizational change factors. Source: adopted by author

\section{EMPLOYEES RESISTANCE TO ORGANIZATIONAL CHANGE}

In every situation, change is something new for employees. Change affect employees because they are going to implement it. They can show positive attitude/behavior (readiness to change) or negative attitude/behavior (resistance to change) to proposed change. When employees show positive attitude, they agree on change and they are motivated to implement it. On the other hand, negative attitudes or behaviors reflect that employees do not agree to organizational change. Resistance to change is considered as a negative attitude of employees to change.

Many change initiatives failure because employees resist to change [8], [10], [12], [13]. Resistance to change creates costs and delays into change management process. So, managers have to take into considerations employees' resistance in order to create u suitable change process. When change is introduced in organization, it produces a range of reactions due to the inherent uncertainty or to the incentives that alter human behavioral patterns such as: status quo, anxiety, lack of tolerance, stress, etc.

Employees resist to organizational change because they fear the undesired consequences. Every change creates a new situation in organization. The process of passing from known to unknown implies uncertainty, therefore individuals' perceived threats towards a state which they knew, controlled and it was a satisfactory stage. Employees have different level of education, backgrounds, experiences, personalities and this impact the way they accept change.

Some authors, divided factors of resistance to change into [7]: a) individual factors; b) group factors and c) organizational factors. Reasons why employees resist to proposed change are different [9]. These authors stressed that the most common reasons employees resist to change are: a) individual interests, b) misunderstandings of change and its implications, c) low tolerance of change.

Other studies have grouped sources of employees' resistance to change into: a) mistrust and lack of confidence; b) emotional response; c) fear of failure; d) poor communication; e) time. Main sources of employees to change are shown in Fig. 2.

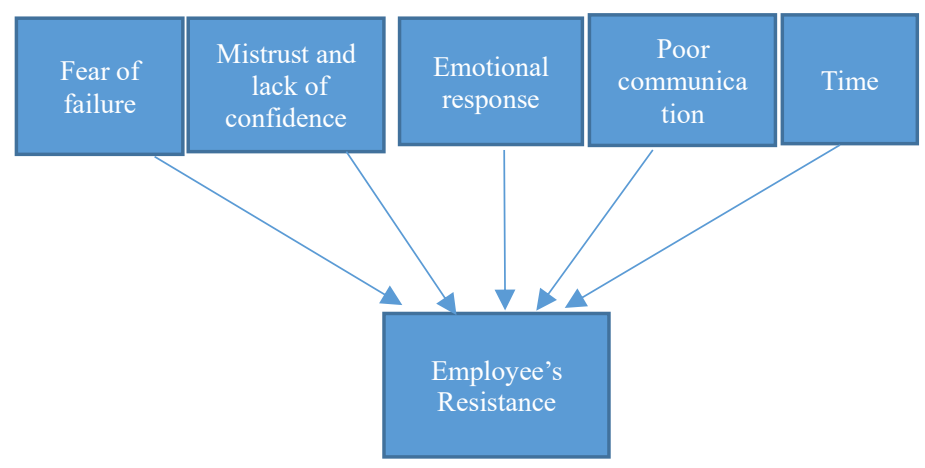

Fig. 2. Sources of employee's resistance to organizational change. Source: Adopted by author.

\section{A. Mistrust and Lack of Confidence}

Lack of confidence is the most common cause of resistance to organizational change. On the other hand, trust in management plays an important role in employees' response to change. If they trust and feel confident with change leader, they are more opened to change otherwise they will refuse it. Employees are more likely to work with leader who understands their needs or daily job problems.

\section{B. Emotional Response}

Some researchers argued that resistance to change is a response of employees needs [3]. Oreg founded in his model of testing resistance that emotional reaction of employees has a strong impact in the employee's rejection to organizational change [11]. 
This is normal because employees react to anything that change their working routine. Managers have to predict these feelings and to understand that for employees change sometimes is accompanied with feelings of lost or unhappiness.

Managers to avoid these feelings have to explain to their employees why change is important to the organizations and to stress the output change is going to provide.

\section{Fear of Failure}

Sometimes, employees have to learn new skills to implement organizational change. Employees may have the desire to be opened to change, but they may feel they do not have the right knowledge or abilities to implement the organizational change. Managers have to value the ability of their employees according to proposed change. If they do not have the proper ability change needs to be successfully implemented, first, employees have to be trained to gain the right knowledge. Then they have to feel comfortable to apply the knowledge they have acquired. So, they feel they have the right silks for implementing the change in organization.

\section{Poor Communication}

Communication is e key element during change process. If employees have lack of information why change is important, what is going to improve the proposed change or has the organization the capacity to undertake the change, probably they are going to refuse it. When organization do not share information to their employees, they feel insignificant to the organization. Also, poor communication creates doubt about change in terms of change aim, change outcomes, etc.

Managers to avoid employee's resistance, must communicate to them and to realize which are the employee's reactions to change. If employees are concerned about change, change agent must motivate them and to explain why change is necessary for the organizations and what it will bring to them.

\section{E. Unrealistic Timelines}

Every change needs time to happen. The amount of time required for change depends on type of organizational change. Time is an essential characteristic of change. Kotter stressed the importance of creating a sense of urgency for change, in his eight steps model, in order that employees accepted it. Although, managers have to find a balance between creation a sense of urgency and the time of transition. Because if you harry up to undertake a change when your organization is not in a crisis's situation employees may resist to accept change as they think maybe change has not been proper evaluated. Employees need time to understand change.

\section{CONCLUSIONS}

This study was focused on factors impose change in organizations. Also, it describes employees' reactions to change and which are the main sources that cause employees resistance to change. Some of this study conclusions are:

- There are external and internal factors that impose organizational change.
- External factors are economic factors, technology, social changes and costumers.

- Internal factors are employees, organizational structure, organizational process.

- Employees have different attitudes regarding change.

- They may show readiness to change or resistance to change

- Resistance to change is an obstacle for change success.

- Employee's source of resistance are: a) mistrust and lack of confidence; b) emotional response; c) fear of failure; d) poor communication; e) time.

\section{REFERENCES}

[1] Bartunek, J. M., Rousseau, D.M., Rudolph, J. M. \& DePalma, J. A. (2006). On the receiving end: Sensemaking, emotion and assessmen of an organizational change initiated by others. The Journal of Applied Behavioral Science, 42, 182-206.

[2] Beer, M. and Nohria, N.,2000, Cracking the code of change. Harvard Business Review, 78, no.3.

[3] Chawla, A. \& Kelloway, E. K. 2004, "Predicting openness and commitment to change", Leadership \& Organization Development Journal, vol. 25, no. 5/6, pp. 485 .

[4] Davis, W. D., \& Gardner, W. L. (2004). Perceptions of politics and organizational cynicism: An attributional and leader-member exchange perspective. Leadership Quarterly, 15(4).

[5] George, J. M. \& Jones, G. R. (2001). Towards a process model of individual change in organizations. Human Relations, 54, 419- 444.

[6] Kiefer, T. (2005). Feeling bad: Antecedents consequences of negative emotions in ongoing change. Journal of Organizational Behavior, 26, 875-89.

[7] Kotter, J. P., \& Schlesinger, L. A. (1979) Choosing strategies for change. Harvard Business Review, 57, 106-114.

[8] Lawrence, P.R. (1954) "How to Deal with Resistance to Change", Harvard Business Review, (May/June), pp. 49-57.

[9] Mabin, Victoria J., Forgeson, Steve and Green, Lawrence (2001) Harnessing resistance: using the theory of constraints to assist change management. Journal of European Industrial Training, 25(2/3): 168191.

[10] Maurer, R. (1996) "Using resistance to build support for change", The Journal for Quality and Participation, 19 (3), pp. 56-66. May-Jun, 133141.

[11] Oreg, S. (2003). Resistance to change: Developing an individual differences measure. Journal of Applied Psychology, 88(4), 680-693. doi: 10.1037/0021-9010.88.4.680.

[12] Strebel, P. (1994) "Choosing the right change path", California Management Review, 36 (2), pp. 29-51.

[13] Waddell, D. and Sohal, A. S. (1998) "Resistance: a constructive tool for change management", Management Decision, 36 (8), pp. 543-548.

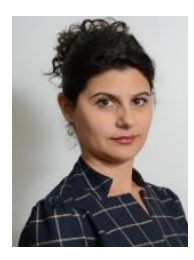

Gentisa Furxhi is a $\mathrm{PhD}$. Candidate in the Economic Faculty of Tirana University. She is an assistant Lecture of the Economic Faculty of "Fan S. Noli" University of Korca. She has a bachelor degree in Business Management at the Economic Faculty of Korca University; The Master degree of Management Hospitality at the "Sv. Kliment Ohridski", North Macedonia. 